シ 餘著 ト

約 $=ナ \overline{\boldsymbol{J}}$ 狀

六大儿提 $九$ 腺

于五分作供力,

口 \% 子用七刀特

キ人「ラ加殊

沃且》上水蛋

范度产口分白

范 7 作 然 ル解質

旨含用然七

狀有ス、ト, バシ

腺シルモモ二チテ

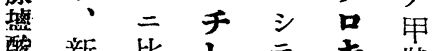

酸新比しテ、キ牀

耤陳較芅强弟腺

キ 謝夲吕弱及沃

灵試量 プ差美

白驗要导教呑大

鼠 蝌 只

器試 然狀 皆 吕 結

牙品三人品合

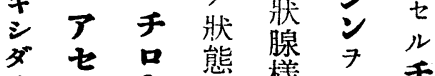

1 上キ態梯生千

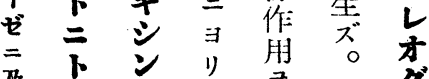

及

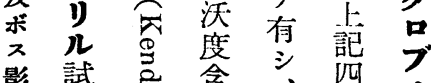

影試总念驗就種 リ

等三量 就種

移示九嵒手物之

本

甲四三名何酸

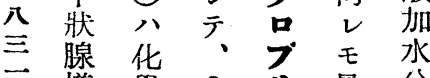

樣學 小 y 最分

作的 $ル \circlearrowright$ 初 解

用純 モ

八粹さチ狀 バ

現ナト腺 $ヨ$

在儿見キ人

又 化 做 シ 作

デ合スシ用 天

二物 二 二 物

知 八 八質

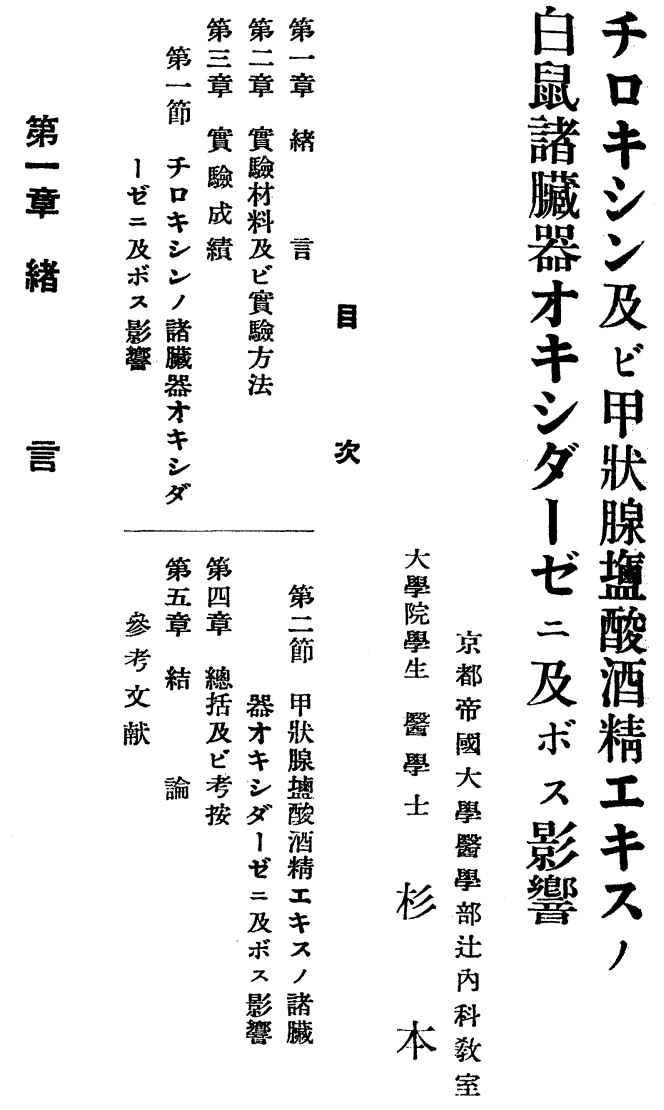

英 


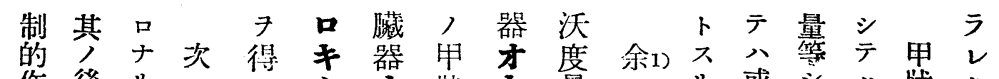

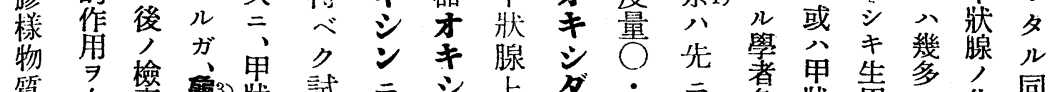

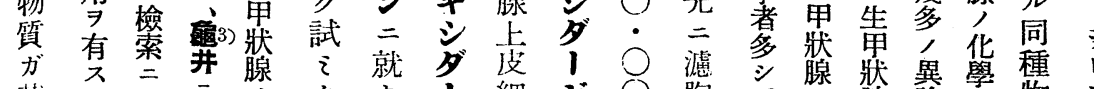

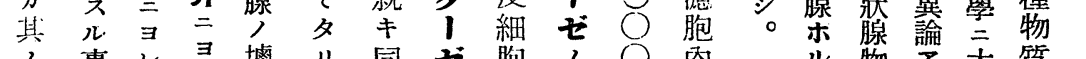

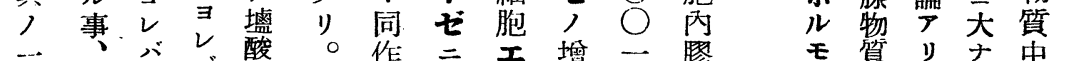

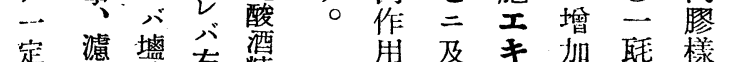

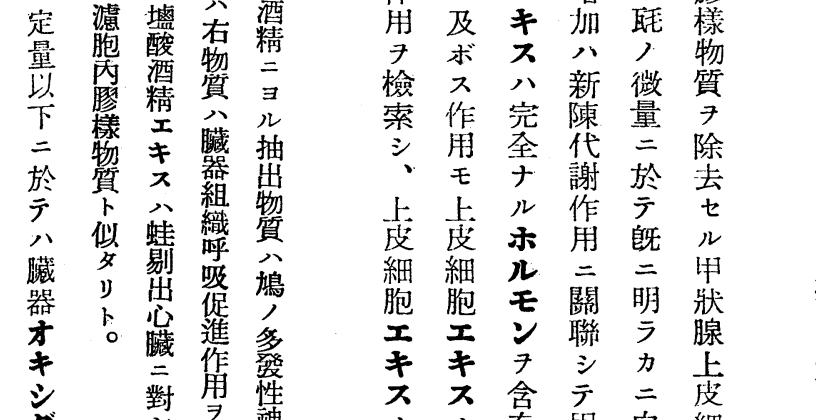

多济有神要, 有甲白細

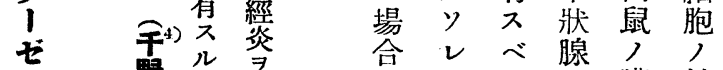
減汿吉治 減或甲癒 七 分桀

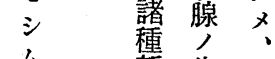

公新生

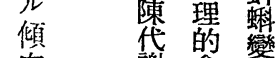

向 謝 食態

有羷水著

ス松年奛

等井开促

泉的作毞

余亩男角事

前思些事

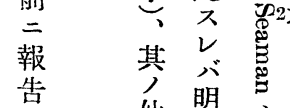

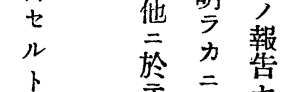

コ密弱

+ 抑

, =

成勝 ガ 特器

績 ル 故殊 才物

卜

比王、作 音藏

較劣于用多器

ス $5 口=1$ 才

ルザキ基ゼキ

コルジク

トべシコ增 ダ

二キ二卜量

ヨ 筈 シ 奧 七

リナテ・シ

チリ用森么及

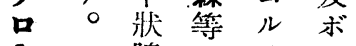

キ $\exists$ 腺,

シ 手明認影

ンテルラメ響

, 余王名

本分 $y=$ 檢

性本子七。索

三䆩り少斯

就驗卜所》吕

- 於 バリ如物

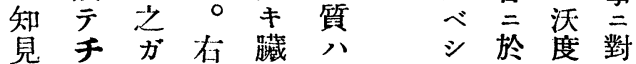

筫当学最

八寻例隻最

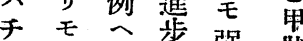

口作 バ劣强 將

キ角生裔力腺

シ弱童せナ搵

ン シ 牀儿酒

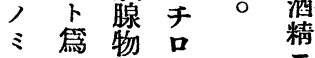

韭シ賀キ 去

ズ或有少 ス

点不登白

齐品見鼠

、物功 諸

或言學績器

、沃作固 才

$\exists$ 度角 $\exists$

1) $=1$ i

晏甲 何出

罍獎示人

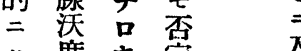

度キ定出

チ部艺得影

キ熬缺ル苞繁

浔

占儿キ

分公モ毛等

牀二是: 本

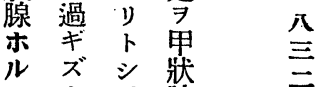

モ $卜$ 、腺

之爲或禾

分不采无

解サ口二

㡾レキト

物 ジ学

于今

几日六事 


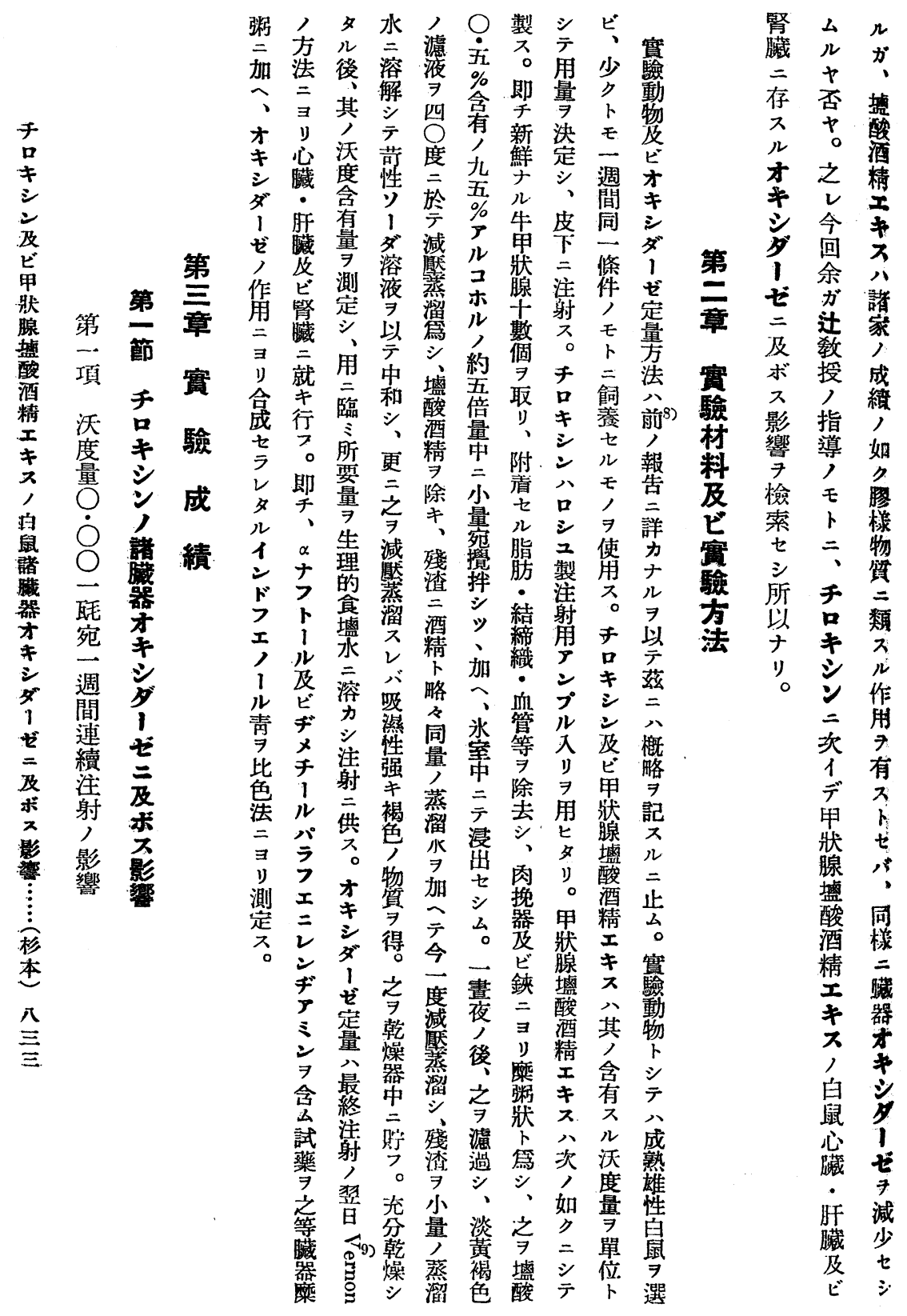


第一表 チロキシン 沃度量 $0.001 \mathrm{mg}$ 宛一適閒

連續注射 =於ケルオキシダーゼ

\begin{tabular}{|c|c|c|c|c|c|c|c|}
\hline \multirow{2}{*}{$\begin{array}{l}\text { 試 } \\
\text { 驗 } \\
\text { 番 } \\
\text { 號 }\end{array}$} & \multirow{2}{*}{$\begin{array}{l}\text { 檢 } \\
\text { 查 } \\
\text { 星 } \\
\text { 附 }\end{array}$} & & \multicolumn{2}{|c|}{$\begin{array}{l}\text { 體 } \\
\text { (桼) }\end{array}$} & \multicolumn{3}{|c|}{ オキシダーゼ量 } \\
\hline & & & $\begin{array}{l}\text { 注開 } \\
\text { 始 } \\
\text { 射時 }\end{array}$ & $\begin{array}{l}\text { 檢 } \\
\text { 查 } \\
\text { 時 }\end{array}$ & 心 & 肝 & 腎 \\
\hline 1 & $9 / X$ & $\begin{array}{l}\text { 注 射動物 } \\
\text { 對 照 動 物 } \\
\text { 㬬減率 (\%) }\end{array}$ & $\begin{array}{l}191 \\
176\end{array}$ & $\begin{array}{l}198 \\
178\end{array}$ & $\begin{array}{r}10.8 \\
9.5 \\
+13.7\end{array}$ & $\begin{array}{r}8.6 \\
9.6 \\
-10.4\end{array}$ & $\begin{array}{r}18.0 \\
16.2 \\
+\mathbf{1 1 . 1}\end{array}$ \\
\hline 2 & $9 / 1 /$ & $\begin{array}{l}\text { 洼 射動 物 } \\
\text { 對 照 動 物 } \\
\text { 增減率 }(\%)\end{array}$ & $\begin{array}{l}178 \\
176\end{array}$ & $\begin{array}{l}179 \\
178\end{array}$ & $\begin{array}{r}11.1 \\
9.5 \\
+16.9\end{array}$ & $\begin{array}{r}9.8 \\
9.6 \\
+\quad 2.1\end{array}$ & $\begin{array}{r}17.7 \\
16.2 \\
+\quad 9.3\end{array}$ \\
\hline 3 & $11 / \prime \prime$ & $\begin{array}{l}\text { 洼 射動 物 } \\
\text { 對 照 動 物 } \\
\text { 堌減率 }(\%)\end{array}$ & $\begin{array}{l}167 \\
157\end{array}$ & $\begin{array}{l}165 \\
163\end{array}$ & $\begin{array}{r}8.3 \\
7.2 \\
+15.3\end{array}$ & $\begin{array}{r}8.3 \\
8.3 \\
\pm \quad 0\end{array}$ & $\begin{array}{r}15.8 \\
14.8 \\
+\quad 6.8\end{array}$ \\
\hline 4 & $11 / \|$ & $\begin{array}{l}\text { 注 射動物 } \\
\text { 對 照動 物 } \\
\text { 堌減率(\%) }\end{array}$ & $\mid \begin{array}{l}148 \\
157\end{array}$ & $\begin{array}{l}140 \\
163\end{array}$ & $\begin{array}{r}7.0 \\
7.2 \\
-\quad 2.8\end{array}$ & $\begin{array}{r}7.7 \\
8.3 \\
-\quad 7.2\end{array}$ & $\begin{array}{r}14.2 \\
14.8 \\
-\quad 0.4\end{array}$ \\
\hline 5 & $12 / / 1$ & $\begin{array}{l}\text { 注 射動物 } \\
\text { 對 照 動 物 } \\
\text { 增減率 (\%) }\end{array}$ & $\left|\begin{array}{l}162 \\
163\end{array}\right|$ & $\begin{array}{l}174 \\
182\end{array}$ & $\begin{array}{r}8.9 \\
9.7 \\
-\quad 8.3\end{array}$ & $\begin{array}{r}13.2 \\
7.3 \\
+80.8\end{array}$ & $\begin{array}{r}16.6 \\
13.0 \\
+27.7\end{array}$ \\
\hline 6 & $12 / "$ & $\begin{array}{l}\text { 注 射動物 } \\
\text { 對照動物 } \\
\text { 增減率 }(\%)\end{array}$ & $\begin{array}{l}164 \\
163\end{array}$ & $\begin{array}{l}176 \\
182\end{array}$ & $\begin{array}{r}8.7 \\
9.7 \\
-10.3\end{array}$ & $\begin{array}{r}7.5 \\
7.3 \\
+\quad 2.7\end{array}$ & $\begin{array}{r}11.8 \\
13.0 \\
-\quad 9.2\end{array}$ \\
\hline 7 & $19 / / 1$ & $\begin{array}{l}\text { 注射動物 } \\
\text { 嚙照動物 } \\
\text { 堌減率 }(\%)\end{array}$ & $\left|\begin{array}{l}159 \\
153\end{array}\right|$ & $\begin{array}{l}167 \\
163\end{array}$ & $\begin{array}{r}9.5 \\
10.1 \\
-\quad 5.9\end{array}$ & $\begin{array}{r}9.5 \\
10.5 \\
-\quad 9.5\end{array}$ & $\begin{array}{r}13.0 \\
12.6 \\
+\quad 3.2\end{array}$ \\
\hline 8 & $19 / 1$ & $\begin{array}{l}\text { 注 射動 物 } \\
\text { 對 照 動 物 } \\
\text { 增減率 (\%) }\end{array}$ & $\begin{array}{l}145 \\
153\end{array}$ & $\mid \begin{array}{l}148 \\
163\end{array}$ & $\begin{array}{r}9.9 \\
10.1 \\
-\quad 2.0\end{array}$ & $\begin{array}{r}9.4 \\
10.5 \\
-\mathbf{1 0 . 5}\end{array}$ & $\begin{array}{r}12.1 \\
12.6 \\
-\quad 4.0\end{array}$ \\
\hline & 增 & 或率平均（） & & & +2.1 & +6.1 & +5.6 \\
\hline
\end{tabular}


第二表 チロキシン 沃度量 $0.01 \mathrm{mg}$ 宛一墹間 連續注射 =於ケルオキシダーゼ

\begin{tabular}{|c|c|c|c|c|c|c|c|}
\hline \multirow{2}{*}{$\begin{array}{l}\text { 試 } \\
\text { 驗 } \\
\text { 番 } \\
\text { 踥 }\end{array}$} & \multirow{2}{*}{$\begin{array}{l}\text { 檢 } \\
\text { 查 } \\
\text { 星 } \\
\text { 附 }\end{array}$} & & \multicolumn{2}{|c|}{$\begin{array}{l}\text { 體 重 } \\
(\text { 瓦) }\end{array}$} & \multicolumn{3}{|c|}{ オキシダーゼ量 } \\
\hline & & & $\begin{array}{c}\text { 注開 } \\
\text { 始 } \\
\text { 射時 }\end{array}$ & \begin{tabular}{|l||} 
檢 \\
臬 \\
\end{tabular} & 心 臟 & 肝 臟 & 腎 \\
\hline 1 & $20 / X$ & 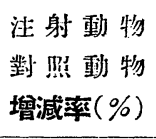 & $\begin{array}{l}173 \\
168\end{array}$ & $\begin{array}{l}178 \\
170\end{array}$ & $\begin{array}{r}8.5 \\
9.9 \\
-\mathbf{1 4 . 1}\end{array}$ & $\begin{array}{r}9.2 \\
10.4 \\
-\mathbf{1 1 . 5}\end{array}$ & $\begin{array}{r}13.6 \\
13.3 \\
+\quad 2.3\end{array}$ \\
\hline 2 & $20 / 11$ & $\begin{array}{l}\text { 注射動 物 } \\
\text { 對 照 動 物 } \\
\text { 缡墄率 (\%) }\end{array}$ & $\begin{array}{l}162 \\
168\end{array}$ & $\begin{array}{l}162 \\
170\end{array}$ & $\begin{array}{r}10.8 \\
9.9 \\
+\quad 9.1 \\
\end{array}$ & $\begin{array}{r}8.8 \\
10.4 \\
-15.4 \\
\end{array}$ & $\begin{array}{r}11.2 \\
13.3 \\
-\mathbf{1 5 . 8} \\
\end{array}$ \\
\hline 3 & $22 / 11$ & $\begin{array}{l}\text { 注射動 物 } \\
\text { 對照動 物 } \\
\text { 媲減率(\%) }\end{array}$ & $\begin{array}{l}144 \\
146\end{array}$ & $\begin{array}{l}152 \\
150\end{array}$ & $\begin{array}{r}11.1 \\
11.9 \\
-\quad 6.7 \\
\end{array}$ & $\begin{array}{r}11.7 \\
12.1 \\
-\quad 3.3 \\
\end{array}$ & $\begin{array}{r}11.7 \\
16.3 \\
-\mathbf{2 8 . 2}\end{array}$ \\
\hline 4 & $22 ; \pi$ & $\begin{array}{l}\text { 注 射動 物 } \\
\text { 對 照 動 物 } \\
\text { 増減率(\%) }\end{array}$ & $\begin{array}{l}146 \\
146\end{array}$ & $\begin{array}{l}150 \\
150\end{array}$ & $\begin{array}{r}10.4 \\
11.9 \\
-12.6\end{array}$ & $\begin{array}{r}11.0 \\
12.1 \\
-\quad 9.1\end{array}$ & $\begin{array}{r}11.8 \\
16.3 \\
-27.6\end{array}$ \\
\hline 5 & $27 / i /$ & $\begin{array}{l}\text { 注射動物 } \\
\text { 凯照動物 } \\
\text { 增減率 (\%) }\end{array}$ & $\begin{array}{l}160 \\
166\end{array}$ & $\begin{array}{l}159 \\
182\end{array}$ & $\begin{array}{r}9.2 \\
9.2 \\
\pm \quad 0\end{array}$ & $\begin{array}{r}9.0 \\
8.2 \\
+\quad 9.8\end{array}$ & $\begin{array}{r}14.0 \\
\mathrm{I} 2.8 \\
+\quad 9.4\end{array}$ \\
\hline 6 & $27 / 11$ & $\begin{array}{l}\text { 注 射動物 } \\
\text { 對照動 物 } \\
\text { 媲減率(\%) }\end{array}$ & $\begin{array}{l}167 \\
166\end{array}$ & $\begin{array}{l}170 \\
182\end{array}$ & $\begin{array}{r}9.0 \\
9.2 \\
-\quad 2.2\end{array}$ & $\begin{array}{r}10.6 \\
8.2 \\
+29.3\end{array}$ & $\begin{array}{r}14.8 \\
12.9 \\
+15.6\end{array}$ \\
\hline 7 & $2 / X l$ & $\begin{array}{l}\text { 注射動物 } \\
\text { 對 照 動 物 } \\
\text { 增減率(\%) }\end{array}$ & $\begin{array}{l}168 \\
174\end{array}$ & $\begin{array}{l}160 \\
174\end{array}$ & $\begin{array}{r}10.5 \\
9.3 \\
+\mathbf{1 2 . 9}\end{array}$ & $\begin{array}{r}10.3 \\
9.4 \\
+\quad 9.6\end{array}$ & $\begin{array}{r}13.7 \\
15.2 \\
-\quad 9.9\end{array}$ \\
\hline 8 & $2 / 11$ & $\begin{array}{l}\text { 注射動物 } \\
\text { 對照動物 } \\
\text { 增減率 (\%) }\end{array}$ & $\begin{array}{l}168 \\
174 \\
\end{array}$ & \begin{tabular}{l|}
160 \\
174
\end{tabular} & $\begin{array}{r}8.9 \\
9.3 \\
-\quad 4.3 \\
\end{array}$ & $\begin{array}{r}11.0 \\
9.4 \\
+17.0 \\
\end{array}$ & $\begin{array}{r}14.1 \\
15.2 \\
-\quad 7.2 \\
\end{array}$ \\
\hline & 堌浱 & 或率平均（） & & & -2.2 & +3.3 & -7.7 \\
\hline
\end{tabular}




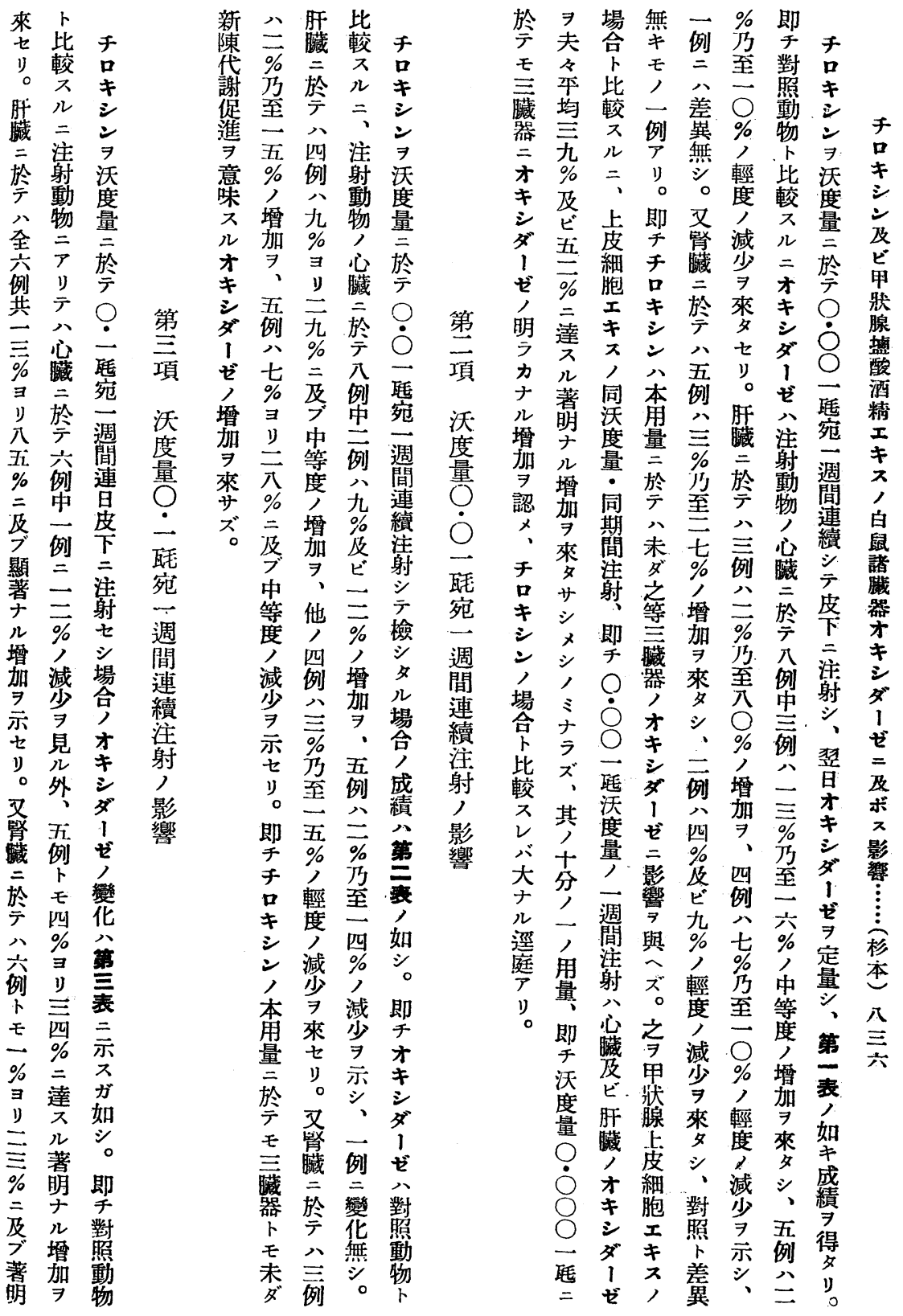


第三表 チロキシン 沃度量 $0.1 \mathrm{mg}$ 宛一䓢間連續注射二於タルオキシダーせ

\begin{tabular}{|c|c|c|c|c|c|c|c|}
\hline \multirow{2}{*}{ 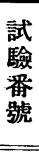 } & \multirow{2}{*}{$\begin{array}{l}\text { 檢 } \\
\text { 昆 } \\
\text { 附 }\end{array}$} & & \multirow{2}{*}{\multicolumn{2}{|c|}{ 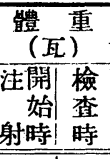 }} & \multicolumn{3}{|c|}{ オキシダーゼ量 } \\
\hline & & & & & 心 & 时 & 腎 \\
\hline 1 & $29 / X$ & $\begin{array}{l}\text { 注 射動 物 } \\
\text { 對照動 物 } \\
\text { 增減率(\%) }\end{array}$ & $\begin{array}{l}170 \\
166\end{array}$ & $\begin{array}{l}175 \\
174\end{array}$ & $\begin{array}{r}9.8 \\
9.4 \\
+\quad 4.3\end{array}$ & $\begin{array}{r}15.0 \\
10.5 \\
+42.8\end{array}$ & $\begin{array}{r}17.8 \\
15.4 \\
+15.6\end{array}$ \\
\hline 2 & $29 / 11$ & $\begin{array}{l}\text { 注 射動 物 } \\
\text { 對 照 動 物 } \\
\text { 增減率 (\%) }\end{array}$ & $\begin{array}{l}163 \\
166\end{array}$ & $\begin{array}{l}159 \\
174\end{array}$ & $\begin{array}{r}12.6 \\
9.4 \\
+34.0\end{array}$ & $\begin{array}{r}15.7 \\
10.5 \\
+49.5\end{array}$ & $\begin{array}{r}16.8 \\
15.4 \\
+\quad 9.1\end{array}$ \\
\hline 3 & $30 / " 1$ & $\begin{array}{l}\text { 注射動 物 } \\
\text { 對照動 物 } \\
\text { 壃減率(\%) }\end{array}$ & $\begin{array}{l}156 \\
156\end{array}$ & $\begin{array}{l}141 \\
152\end{array}$ & $\begin{array}{r}9.5 \\
\cdot \quad 8.7 \\
+\quad 9.2 \\
\end{array}$ & $\begin{array}{r}10.1 \\
8.9 \\
+13.5\end{array}$ & $\begin{array}{r}10.4 \\
10.3 \\
+\quad 1.0\end{array}$ \\
\hline 4 & $30 / 11$ & $\begin{array}{l}\text { 注 射動 物 } \\
\text { 對照 動 物 } \\
\text { 増減率 (\%) }\end{array}$ & $\begin{array}{l}148 \\
156\end{array}$ & $\mid \begin{array}{l}146 \\
152\end{array}$ & $\begin{array}{r}7.6 \\
87 \\
-12.6\end{array}$ & $\begin{array}{r}14.2 \\
8.9 \\
+59.5\end{array}$ & $\begin{array}{r}12.7 \\
10.3 \\
+23.3\end{array}$ \\
\hline 5 & $3 / \mathrm{XI}$ & $\begin{array}{l}\text { 注 射 動 物 } \\
\text { 對 照 動 物 } \\
\text { 增隇率(\%) }\end{array}$ & $\begin{array}{l}168 \\
174\end{array}$ & $\begin{array}{l}175 \\
187\end{array}$ & $\begin{array}{r}9.5 \\
7.8 \\
+21.8\end{array}$ & $\begin{array}{r}15.2 \\
8.2 \\
+85.3\end{array}$ & $\begin{array}{r}17.3 \\
16.5 \\
+\quad 4.9\end{array}$ \\
\hline 6 & $3 / 11$ & $\begin{array}{l}\text { 注 射 動 物 } \\
\text { 對 照 動 物 } \\
\text { 增減率(\%) }\end{array}$ & $\begin{array}{l}177 \\
174\end{array}$ & $\begin{array}{l}180 \\
187\end{array}$ & $\begin{array}{r}8.8 \\
7.8 \\
+\mathbf{1 2 . 8}\end{array}$ & $\begin{array}{r}14.3 \\
8.2 \\
+74.4\end{array}$ & $\begin{array}{r}17.7 \\
16.5 \\
+\quad 7.3\end{array}$ \\
\hline & & 或率平均（） & & & +11.6 & +46.8 & +10.2 \\
\hline
\end{tabular}

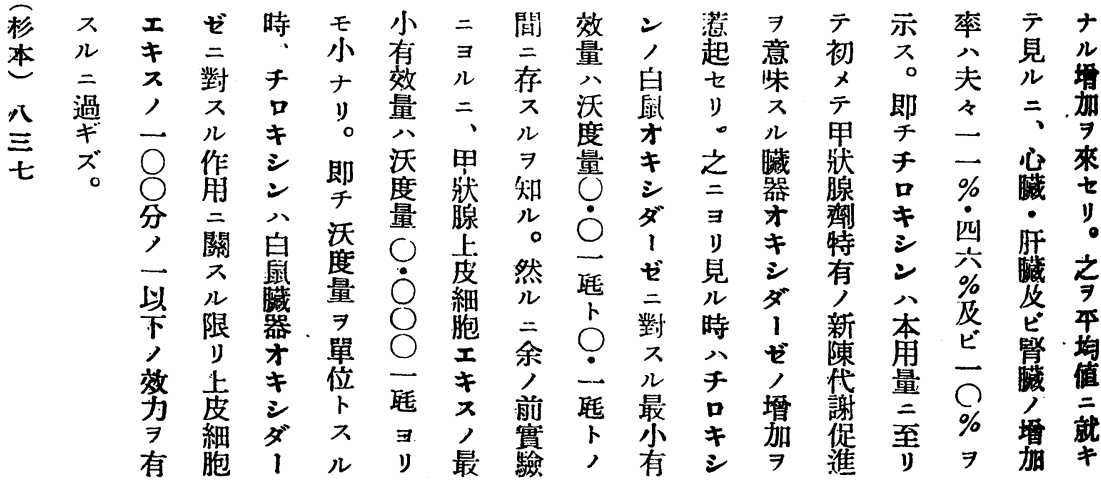


第四表 甲狀腺覤酸酒精エキス 沃度量 $0.001 \mathrm{mg}$ 宛

一週間連續注射 ニ於ヶルオキシダーゼ

\begin{tabular}{|c|c|c|c|c|c|c|c|}
\hline \multirow{2}{*}{$\begin{array}{l}\text { 武 } \\
\text { 驗 } \\
\text { 番 } \\
\text { 號 } \\
\end{array}$} & \multirow{2}{*}{$\begin{array}{l}\text { 檢 } \\
\text { 查 } \\
\text { 日 } \\
\text { 附 }\end{array}$} & \multirow[b]{2}{*}{ - } & \multirow{2}{*}{\multicolumn{2}{|c|}{ 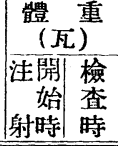 }} & \multicolumn{3}{|c|}{ オキシダーゼ量 } \\
\hline & & & & & 心 & 㸸 & 腎 \\
\hline 1 & $16 / \mathrm{XI}$ & $\begin{array}{l}\text { 注射動 物 } \\
\text { 對照動 物 } \\
\text { 増減率 (\%) }\end{array}$ & $\begin{array}{l}191 \\
182\end{array}$ & $\begin{array}{l}200 \\
193\end{array}$ & $\begin{array}{r}12.5 \\
11.8 \\
+\quad 5.9\end{array}$ & $\begin{array}{r}12.8 \\
11.1 \\
+15.3\end{array}$ & $\begin{array}{r}15.4 \\
14.8 \\
+\quad 4.1\end{array}$ \\
\hline 2 & $16 / " \prime$ & $\begin{array}{l}\text { 注 射動 物 } \\
\text { 對 照 動 物 } \\
\text { 堌減率 (\%) }\end{array}$ & $\begin{array}{l}162 \\
182\end{array}$ & $\begin{array}{l}169 \\
193\end{array}$ & $\begin{array}{r}9.8 \\
11.8 \\
-16.9\end{array}$ & $\begin{array}{r}12.6 \\
11.1 \\
+15.3\end{array}$ & $\begin{array}{r}15.4 \\
14.8 \\
+\quad 4.1\end{array}$ \\
\hline 3 & $18 / 1 /$ & $\begin{array}{l}\text { 注 射動 物 } \\
\text { 對 照 動 物 } \\
\text { 堌減率 (\%) }\end{array}$ & $\begin{array}{l}165 \\
163\end{array}$ & $\begin{array}{l}171 \\
172\end{array}$ & $\begin{array}{r}9.6 \\
10.9 \\
-11.9\end{array}$ & $\begin{array}{r}8.4 \\
11.6 \\
-27.6\end{array}$ & $\begin{array}{r}14.0 \\
14.7 \\
-\quad 4.8\end{array}$ \\
\hline 4 & $18 / / 1$ & $\begin{array}{l}\text { 注 射動 物 } \\
\text { 對 照 動 物 } \\
\text { 增減率(\%) }\end{array}$ & $\begin{array}{l}168 \\
167\end{array}$ & $\begin{array}{l}177 \\
177\end{array}$ & $\begin{array}{r}9.9 \\
10.9 \\
-\quad 9.2 \\
\end{array}$ & $\begin{array}{r}11.3 \\
11.6 \\
-\quad 2.6 \\
\end{array}$ & $\begin{array}{r}15.1 \\
14.7 \\
+\quad 2.7\end{array}$ \\
\hline 5 & $19 / / 1$ & $\begin{array}{l}\text { 注 射動 物 } \\
\text { 對 照 動 物 } \\
\text { 増減率 (\%) }\end{array}$ & $\begin{array}{l}180 \\
177\end{array}$ & $\begin{array}{l}190 \\
180\end{array}$ & $\begin{array}{r}8.7 \\
10.2 \\
-14.7\end{array}$ & $\begin{array}{r}10.0 \\
10.7 \\
-\quad 6.5\end{array}$ & $\begin{array}{r}13.1 \\
11.9 \\
+10.1\end{array}$ \\
\hline 6 & $19 / \|$ & $\begin{array}{l}\text { 注 射 動 物 } \\
\text { 對 照 動 物 } \\
\text { 増減率 (\%) }\end{array}$ & $\begin{array}{l}174 \\
177\end{array}$ & $\begin{array}{l}174 \\
180\end{array}$ & $\begin{array}{r}8.1 \\
10.2 \\
-20.6\end{array}$ & $\begin{array}{r}9.7 \\
10.7 \\
-\quad 9.3\end{array}$ & $\begin{array}{r}10.8 \\
11.9 \\
-\quad 9.2\end{array}$ \\
\hline & & 減率平均（ & $\%)$ & & -11.2 & -2.9 & $+1,2$ \\
\hline
\end{tabular}

示八中ル八注如ゼ連沃

シ三等モ、公射 シ $尹$ 續度甲

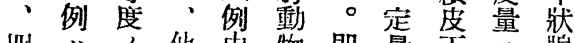

监八分他中物即量下腺

例二減, 一, 子沓三於盐

八三少五例心對 シ 注年 酸

三 \% $\%$ 例, 臓照成射 $\bigcirc$ 酒

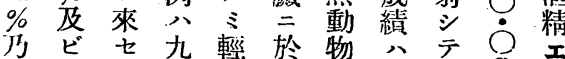

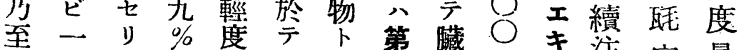

五。扔主才比四器二藏宛量

七\% 肝至增 キ較罫才矮

$\%$ 贜、云 加

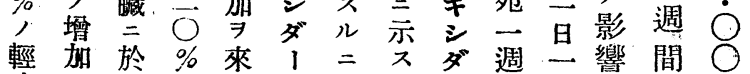

度 $コ$ テ セゼ、ガ、間回

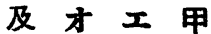

ボキキ狀

スシ

影ダノ墥

1. 諸 酸

モ臟 酒

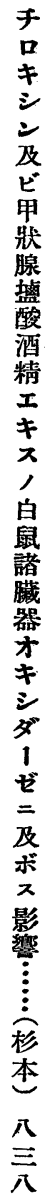




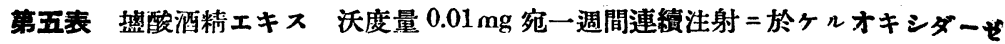

\begin{tabular}{|c|c|c|c|c|c|c|c|}
\hline \multirow{2}{*}{$\begin{array}{l}\text { 試 } \\
\text { 驗 } \\
\text { 番 } \\
\text { 號 }\end{array}$} & \multirow{2}{*}{$\begin{array}{l}\text { 檢 } \\
\text { 查 } \\
\text { 星 } \\
\text { 附 }\end{array}$} & & \multicolumn{2}{|c|}{\begin{tabular}{|l} 
體 \\
(瓦)
\end{tabular}} & \multicolumn{3}{|c|}{ オキシダーゼ量 } \\
\hline & & & $\mid \begin{array}{l}\text { 乼開 } \\
\text { 始 } \\
\text { 射時 }\end{array}$ & \begin{tabular}{|l} 
檢 \\
查 \\
時
\end{tabular} & 心 & 肝 & 腎 \\
\hline 1 & $21 / X \Pi$ & $\begin{array}{l}\text { 注 射動 物 } \\
\text { 跱照 動 物 } \\
\text { 增減率 (\%) }\end{array}$ & $\begin{array}{l}175 \\
172\end{array}$ & $\begin{array}{l}183 \\
185\end{array}$ & $\begin{array}{r}10.4 \\
9.9 \\
+\quad 5.1\end{array}$ & $\begin{array}{r}10.5 \\
10.5 \\
\pm \quad 0\end{array}$ & $\begin{array}{r}16.4 \\
13.0 \\
+26.2\end{array}$ \\
\hline 2 & $21 / "$ & $\begin{array}{l}\text { 注 射動物 } \\
\text { 對照動 物 } \\
\text { 增減率 (\%) }\end{array}$ & $\begin{array}{l}166 \\
172\end{array}$ & $\begin{array}{l}176 \\
185\end{array}$ & $\begin{array}{r}10.5 \\
9.9 \\
+\quad 6.1\end{array}$ & $\begin{array}{r}10.1 \\
10.5 \\
-\quad 3.8\end{array}$ & $\begin{array}{r}15.2 \\
13.0 \\
+16.9\end{array}$ \\
\hline 3 & $23 / " 1$ & $\begin{array}{l}\text { 注射動物 } \\
\text { 對照動 物 } \\
\text { 増減率(\%) }\end{array}$ & $\begin{array}{l}240 \\
238\end{array}$ & $\begin{array}{l}238 \\
250\end{array}$ & $\begin{array}{r}9.1 \\
8.3 \\
+\quad 8.8\end{array}$ & $\begin{array}{r}9.0 \\
9.0 \\
\pm \quad 0\end{array}$ & $\begin{array}{r}14.2 \\
11.8 \\
+20.3\end{array}$ \\
\hline 4 & $25 / 11$ & $\begin{array}{l}\text { 注射動物 } \\
\text { 對照動 物 } \\
\text { 壇減率(\%) }\end{array}$ & \begin{tabular}{|l|}
167 \\
153
\end{tabular} & $\begin{array}{l}182 \\
156\end{array}$ & $\begin{array}{r}9.6 \\
8.7 \\
+10.3\end{array}$ & $\begin{array}{r}10.6 \\
8.4 \\
+26.2\end{array}$ & $\begin{array}{r}14.6 \\
9.2 \\
+58.7\end{array}$ \\
\hline 5 & $25 / 11$ & $\begin{array}{l}\text { 注射動 物 } \\
\text { 数照動 物 } \\
\text { 壃減率 (\%) }\end{array}$ & $\begin{array}{l}146 \\
153\end{array}$ & $\begin{array}{l}152 \\
156\end{array}$ & $\begin{array}{r}108 \\
8.7 \\
+24.1 \\
\end{array}$ & $\begin{array}{r}13.2 \\
8.4 \\
+57.1 \\
\end{array}$ & $\begin{array}{r}15.5 \\
9.2 \\
+68.5 \\
\end{array}$ \\
\hline & & 或率平均 19 & & & +10.9 & +15.9 & +38.1 \\
\hline
\end{tabular}

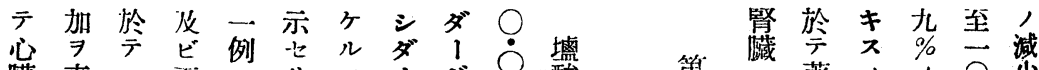

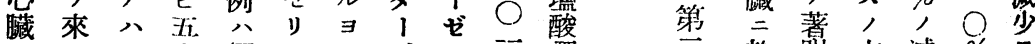

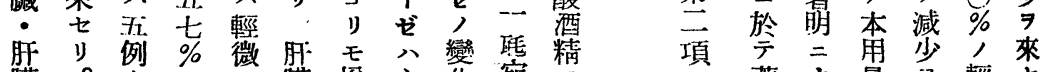

$$
\begin{aligned}
& \text { 藏。十人, 臟增心花宛吕著才量 } \exists \text { 輕七 } \\
& \text { 及 即モ著減文加臓策週 }
\end{aligned}
$$

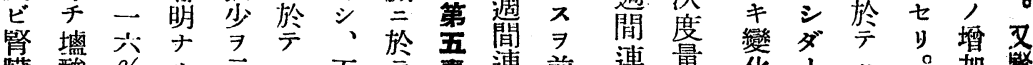

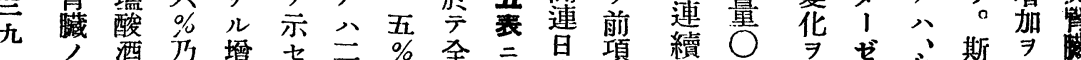

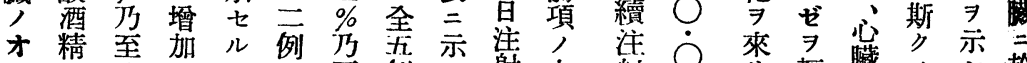

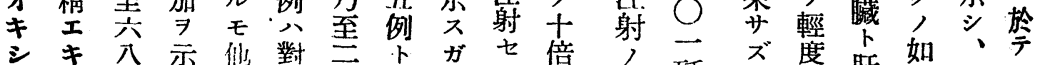

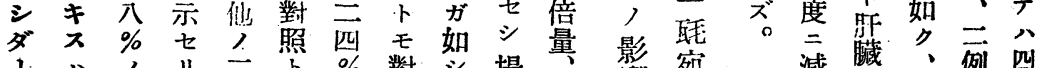

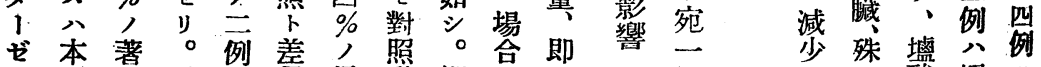

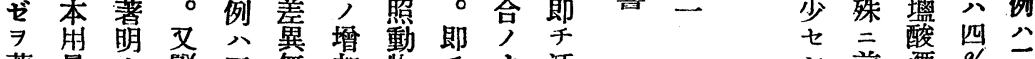

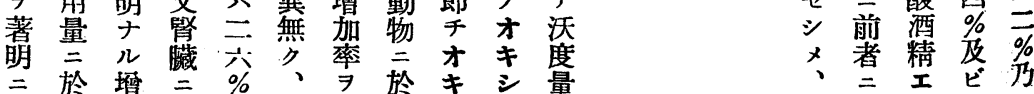




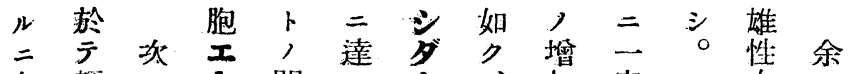

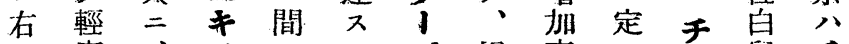

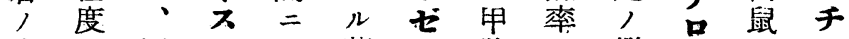

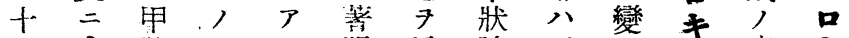

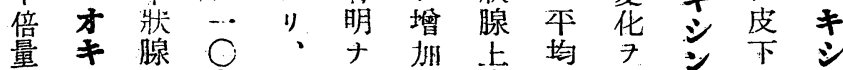

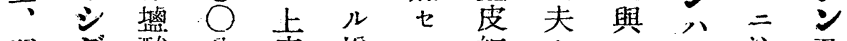
即多酸 分皮增 三細々合每注及 千 1 酒, 細妿メ、胞一元早射ビ 沃 せ 量減 $キ$ 年度

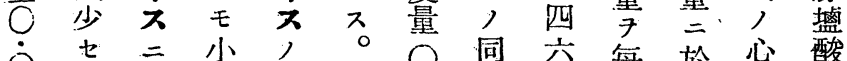

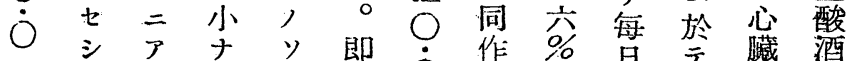

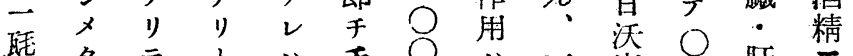

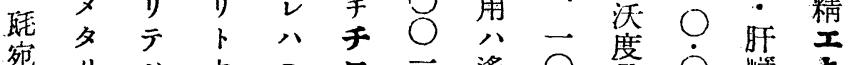
宛! 八t

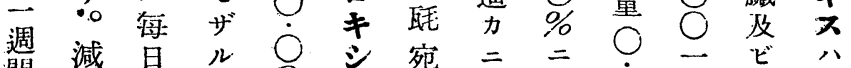

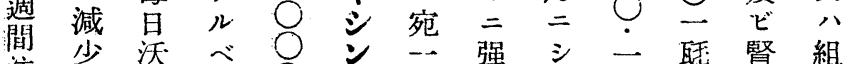

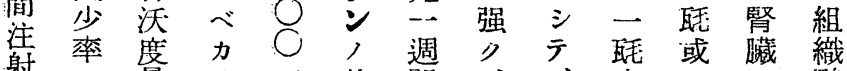
射 量 5 此間、、宛八二 酸

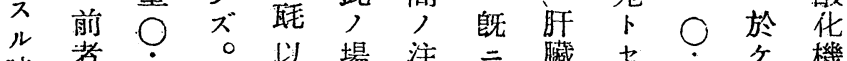
時者 $\dot{0}$ 以場注二臟七宁機 八於 $\bigcirc$ 合 射沃

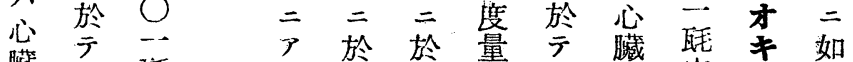

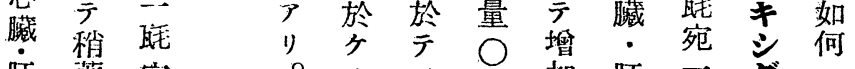
旰萻宛。只守加旰 臟明 一 故最心 $\bigcirc$ 最臟週、作 及ナ週二小贜 ○毛・間せ用 ビり間有及 $○$ 高腎連チス 腎。連品 效

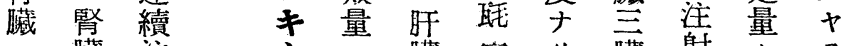

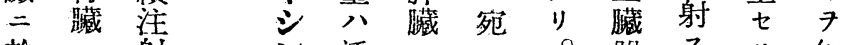
於二射 $\quad$ 沃 $=\overrightarrow{0}$ 器 $ᄌ$ 少知

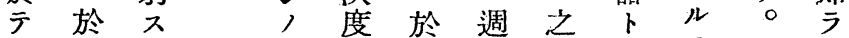
才テ本量年間三モモ其シ 分事作三年淮比才之;卜 明二用於均射三等成欲

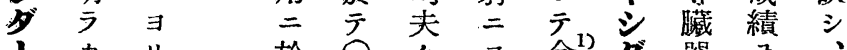
力丨於 $\bigcirc$ \&

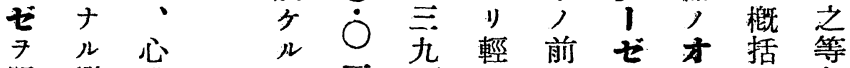

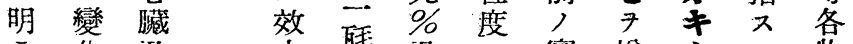
今化及力皌及三實堆 $心$ 物 力無 ビ 八占ビ臟驗出ダバ質

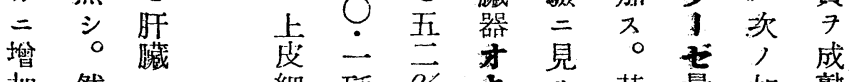
加然二細 狂 $\overrightarrow{\%} \neq$ 其量如熟

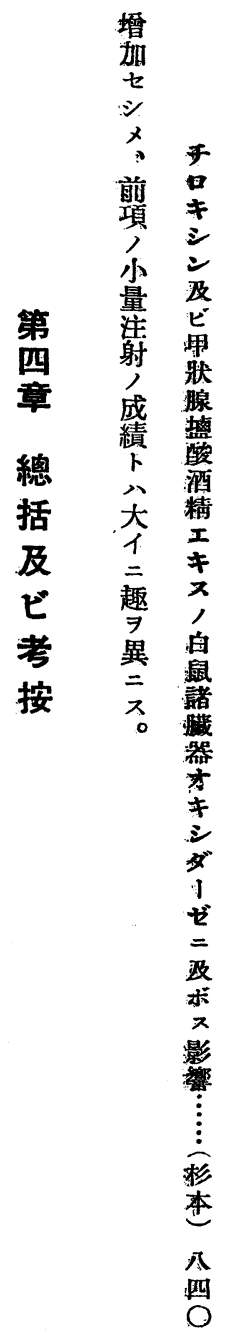




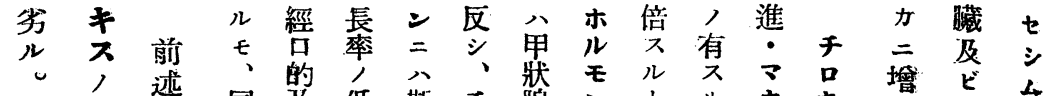

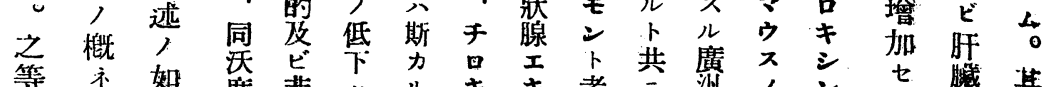

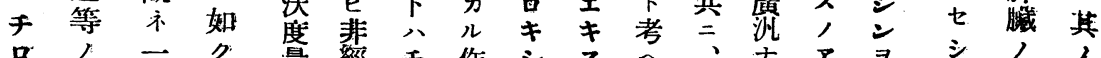
口

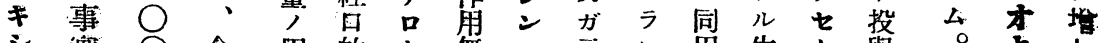

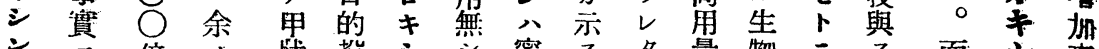

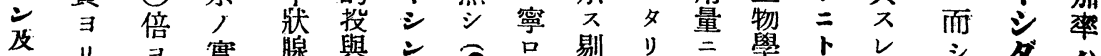
ビ リ ヨ 實 腺與 ニ

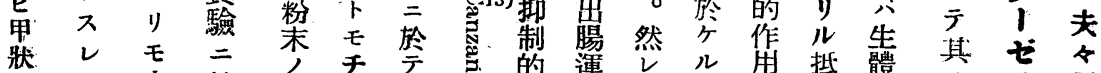

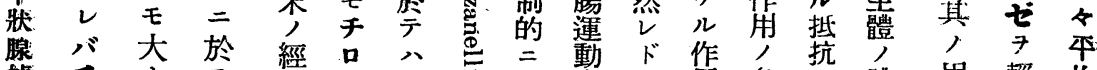

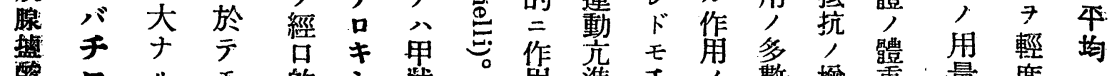

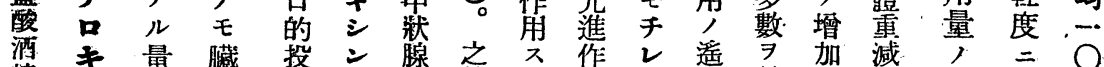
精 キ 量 臟 投

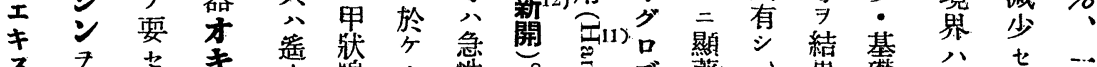

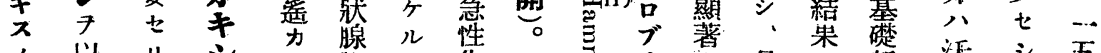

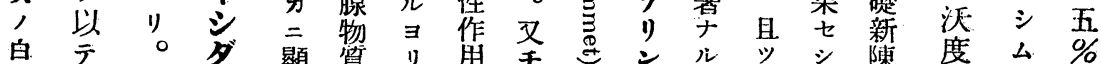

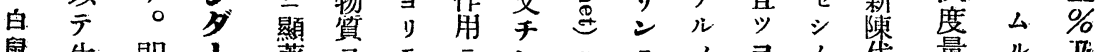

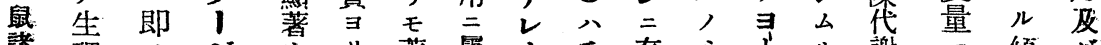

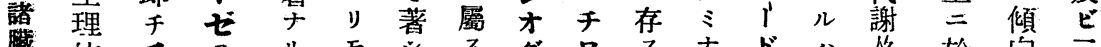

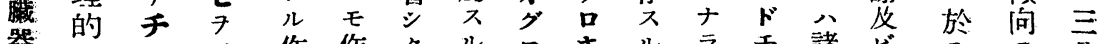

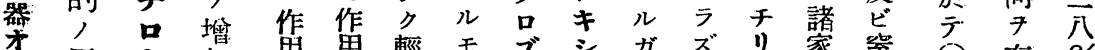

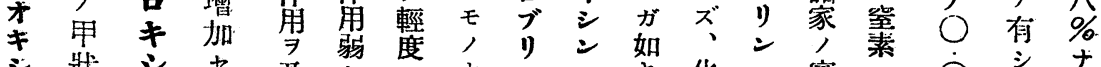
シ 狀 シ セ 学 ダ腺 ン シ

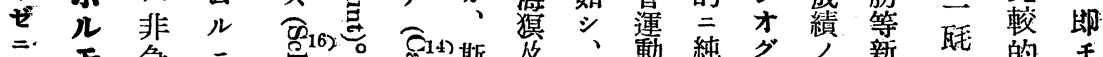
及モ 急 、

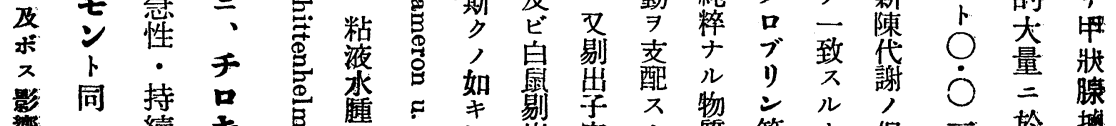

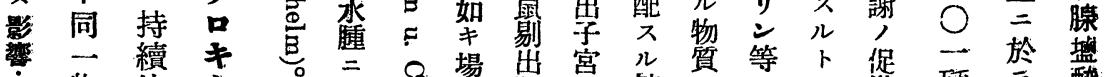

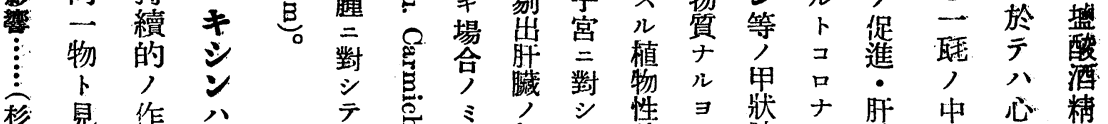

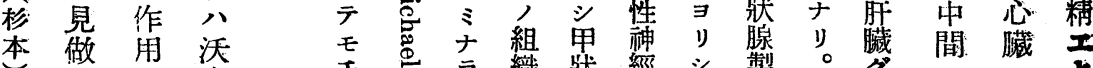

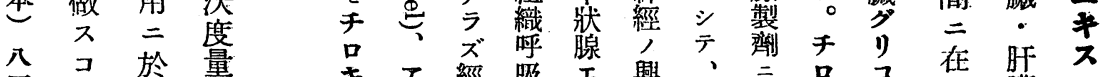
四卜 テ 一八モ於 困甲テ 難 狀甲注卢投七保淮數度公消腎的

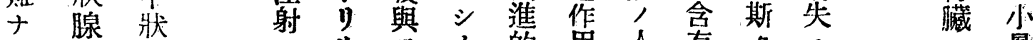
リ物腺 八ル人公的用人有》连量

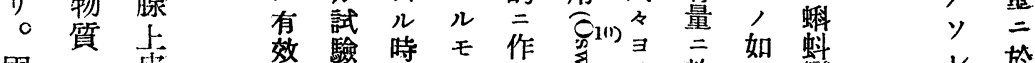

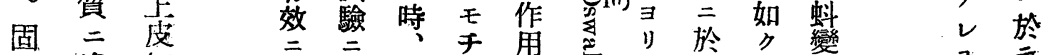
潘 細

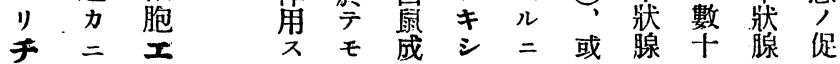

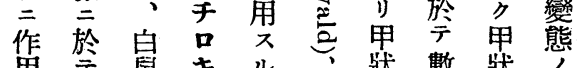




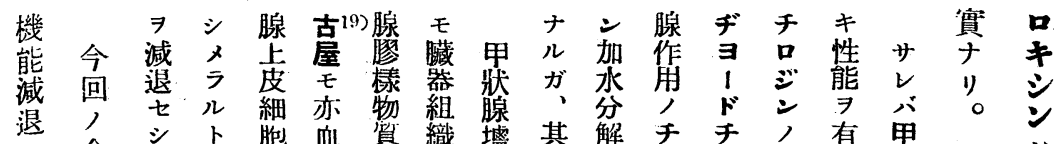

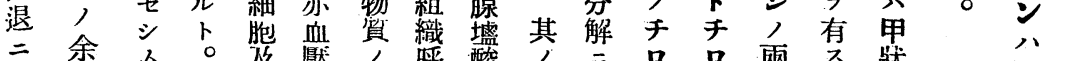

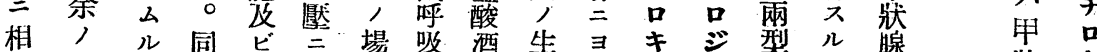

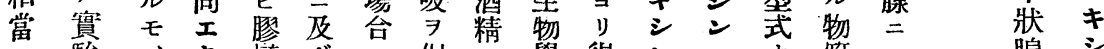

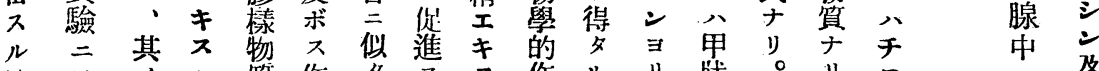

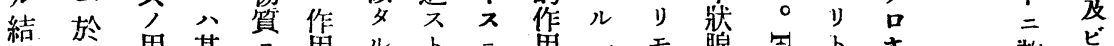

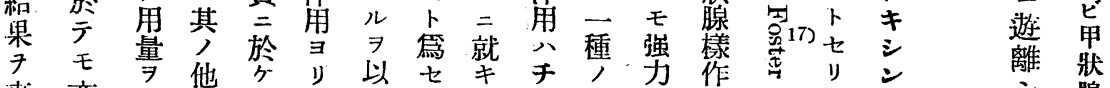
來亦增基儿垎 $テ$ リ ス此不楚沃酸、。八 二較二新度酒. 膠然、汇菅沃微レ狀三士存酸

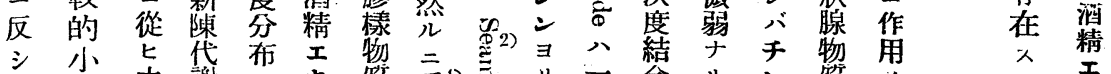

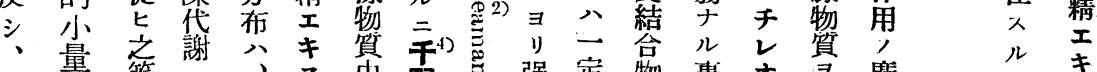

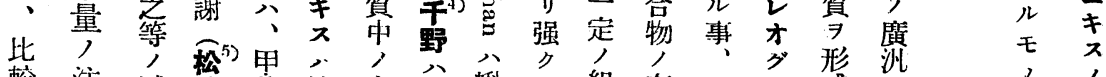

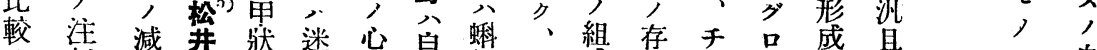

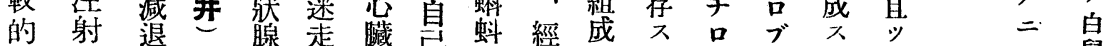

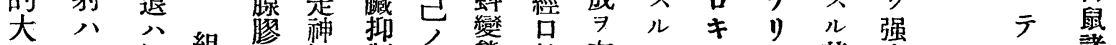

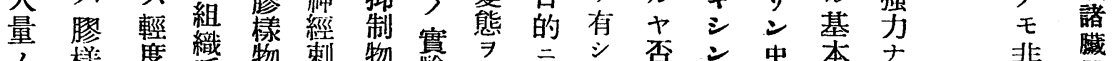

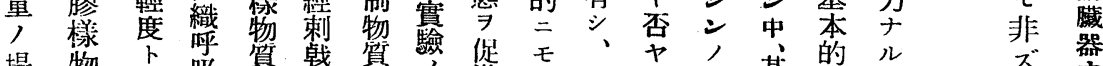

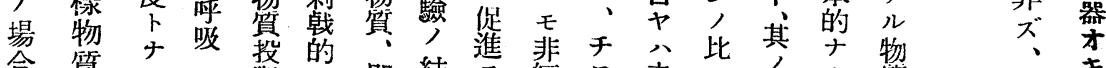

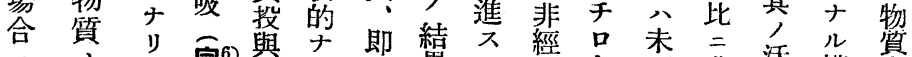

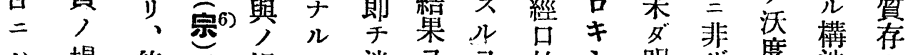

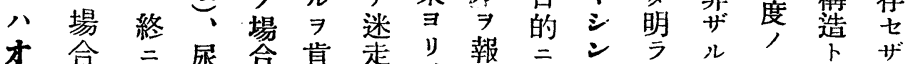

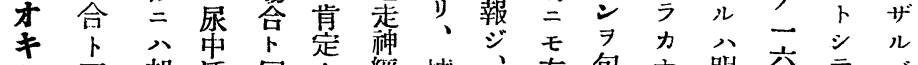

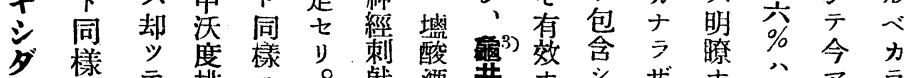

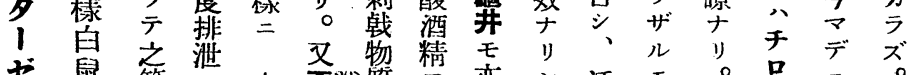

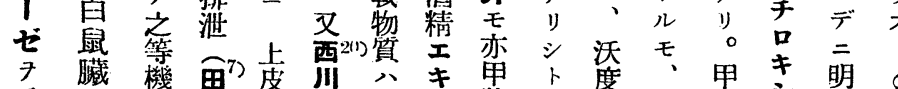

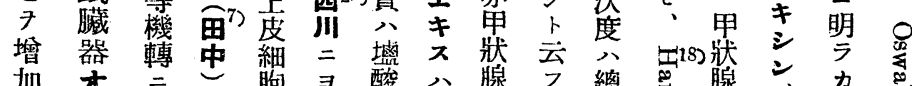

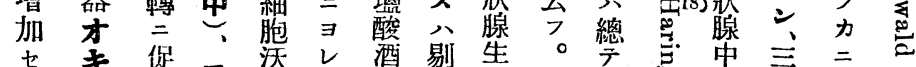

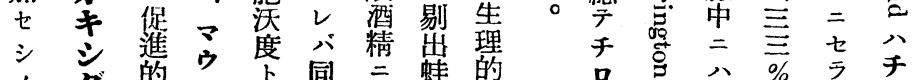

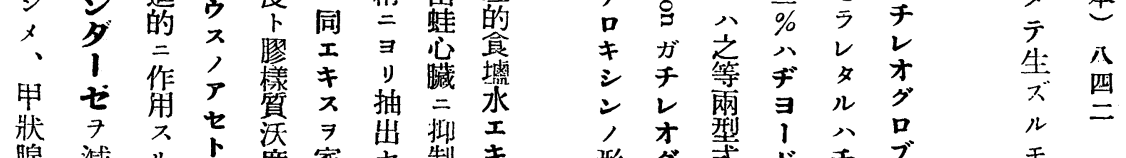

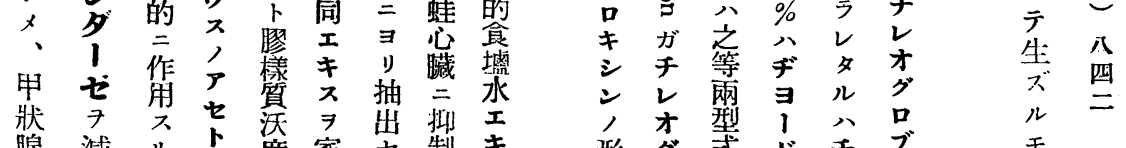
腺減ルさ度家セ制キ形名式ドチブ

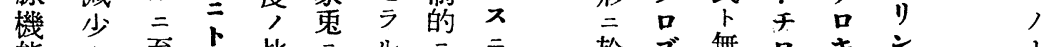
能七至 荒 二、抗 シ

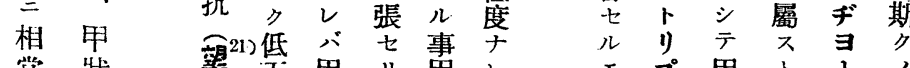

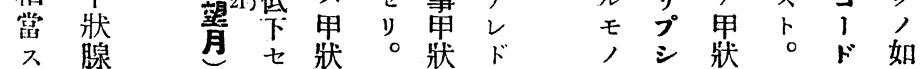


三 $\quad$ ‡

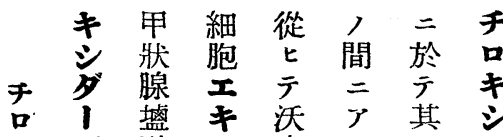

キせ酸 ス度りノン

斗酒)量。增八

及 輕 精 百 尹 加之

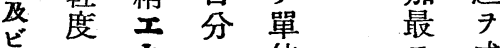

占二丰了位成

桀減 万人著熟

缐少 以草

酸シ其 基

酒

精

工

平

キ

, = 熟

白於 雄

鼠 テ 性

諸 明 白

欌 今鼠

器力度

キナ下

シ ル 二

ダ 變 注

卢花 射

ぜ

及見 ル

ボズ 時

影腹

響岕

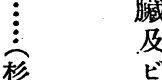

本

八

四
ナ性

り白

而疲

视

テ =

此 注

了射

場 ス

合 ル

了=

千 心

* 臟

7

增

扣

七

シ 最及

ル 有 腎

作 效 臟

心 用 量 =

ビ

臟

㱠

殊

前

者

二

$\exists$

リ

著

$\begin{array}{ll}\text { 明 } & \text { 腺 } \\ \text { オ } & \text { 卢 }\end{array}$
人分於

强 沃 テ

サ

概

天

度才

量 キ

於

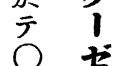

○

( ) 增

眩加

$\stackrel{1}{\circ} \quad$

$\because 4$

毦肝
庆口品量着

度ナ早二二七變

化り狀 シ 於 シ 化

合。腺テテハォ

物 斯 機、小使 招

ノ》能之同用棑

存, 等 機七七

ス 如一兩能 ル

ル角物充該。

第 書

五 八狀

草種腺 シ 量 シ人的

々 二厶

結ナ對卜適結量ル

ルシ七當果ノ二

意小 小期 $尹$ 相、

味量 、間生異忍

於於甲用 シ 基豆

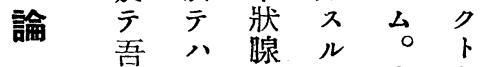

人抑機 時之考并

制能 促頪

自二常進等儿驗

二、ノ 七 ル

值大動 ル 現 即千

ス量物 甲 像 千 野

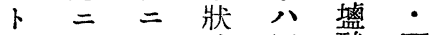

考於對腺 沃酸 西

人 方機度酒川

ラ 八テ能加精

ル促モ $尹$ 里 其

集斯低主升他

的ク下手六他

作如 シ 寻小貿

用キ山代量驗

ス傾ル毛二ト

ル向モ於ガ

-.ア、ジテ相

群儿過ソ 次

ノ八度二甲

甲㯲二モ狀

狀々 用認腺方

腺見 フメ機如

三ラル ラ 能 キ

閵 ル 時 ル 低結

係、公、下果

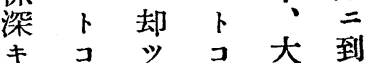




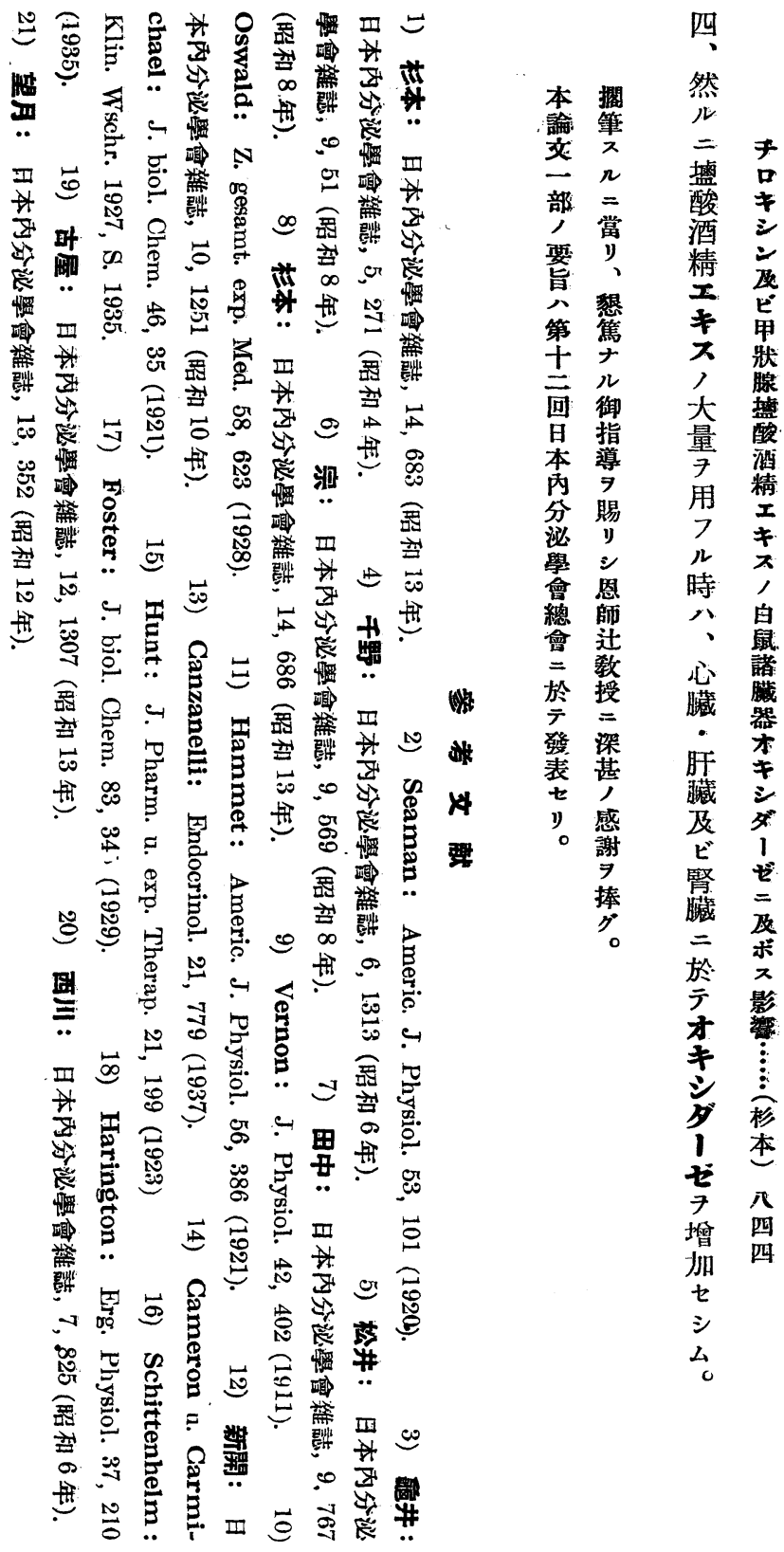


Calciums. Der K/Ca-Quotient zeigte dementsprechend deutliche Abnahme.

2) Injizierte man dem Tier eine kleine Dosis vom salinen Extrakt des Rückstandes bei der Salzsäure-Alkoholextraktion (pro Kilo Körpergewicht $0.012 \mathrm{mg}$ Jod entsprechend), so nahm das Kalium deutlich ab und das Calcium leicht zu. Der K/Ca-Quotient zeigte dementsprechend deutliche Abnahme. Nach der Injektion einer relativ grossen Menge desselben (pro Kilo Körpergewicht $0.02 \mathrm{mg}$ Jod entsprechend) fanden sich deutliche Zunahme des Kaliums und Abnahme des Calciums. Der $\mathrm{K} / \mathrm{Ca}$-Quotient liess dementsprechend deutlichen Anstieg erkennen.

3) Durch die Injektion von $0.05 \mathrm{~g}$ Basedowharnsubstanz (ca. $0.004 \mathrm{mg}$ Jod enthaltend) nahm das Kalium deutlich ab und das Calcium leicht zu. Dementsprechend zeigte der K/Ca-Quotient deutliche Abnahme.

(Autoreferat)

\section{Über den Einfluss von Thyroxin (Roche) und Salzsäure-Alkoholextrakt der Schilddrüse auf die Gewebsoxydase der weissen Ratten.}

Von

Dr. E. Sugimoto.

(Aus der 1. Med. Klinik der Kaiserl. Universität zu Kyoto in Japan.

Direktor: Prof. Dr. K. Tsuji)

Im Anschluss an 2 frühere Mitteilungen versuchte dẹ Verfasser in dieser Arbeit, den Einfluss von Thyroxin und Salzsäure-Alkoholextrakt der Schilddrüse auf den Oxydasegehalt der verschiedenen Organe festzustellen. Als Versuchstier dienten stets ausgewachsene männliche weisse Ratten. Der Salzsäure-Alkoholextrakt der- Schilddrüse wurde auf folgende Weise hergestellt: Über 10 Stück frische Rinderschilddrüsen wurden zuerst von Fett, Bindegewebe und Blut- 
gefässen möglichst frei gemacht und alsdann zu Brei zermörsert. Dieser Brei wurde mit seiner 5 fachen Menge 95\%igen zu $0.5 \%$ salzsäurehaltigen Alkohols 24. Stunden lang im Eisschrank extrahiert und darauf abfiltriert. Das Filtrat wurde unter Abdruck abgedampft, 2 mal mit destiliertem Wasser gewaschen, mit Natronlauge neutralisiert und dann getrocknet. Das so erhaltene Pulver wurde bei der Injektion jeweils in physiologische Kochsalzlösung gelöst und dann subkutan eingespritzt.

Die sonstigen Versuchsanordnungen waren wie die in den früheren Mitteilungen. Die Versuchsergebnisse lassen sich etwa wie folgt zusammenfassen :

1) Die eine Woche lang fortgesetzte Injektion von 'Thyroxin (pro Tag $0.1 \mathrm{mg}$ Jod entsprechend) verursachte Zunahme der Oxydase im Herzen, in der Leber und Niere. Diese Zunahme der Oxydase war am stärksten in der Leber. Die minimale wirksame Dosis von Thyroxin liegt hierbei in Jodgehalt umgerechnet $\mathrm{zw}$ ischen $0.01 \mathrm{mg}$ und $0.1 \mathrm{mg}$.

2) Daraus folgt, dass die oxydasevermehrende Wirkung von Thyroxin weit hinter der des Epithelzellenextraktes der Schilddrüse, in Jodgehalt umgerechnet ca. 1/100 des letzteren, zurücktritt.

3) Bei der eine Woche lang fortgesetzten Injektion einer kleinen Dosis von Salzsäure-Alkoholextrakt der Schilddrüse (pro Tag 0.001 mg Jod entsprechend) kam es zur leichten Abnahme der Oxydase im Herzen und in der Leber. Auf die Oxydase der Niere übte der Salzsäure-Alkoholextrakt der Schilddrüse in dieser Dosis keinen nennenswerten Einfluss aus.

4) Injizierte man aber eine relativ grosse Menge von SalzsäureAlkoholextrakt der Schilddrüse (pro Tag $0.01 \mathrm{mg}$.Jod entsprechend), so kam es zur Zunahme der Oxydase im Herzen, in der Leber und Niere.

(Autoreferat)

\section{Über den Einfluss von Jodkalium und Dijodtyrosin auf die Gewebsoxydase der weissen Ratten.}

